\title{
Fungal Quality of Fresh Shrimp Sold at Ndibe-Beach in Afikpo, Ebonyi State.
}

\author{
Orji Jerry $\mathrm{O}^{1}$., Ekuma Uchechukwu $\mathrm{O}^{1}$., Agah Maduka $\mathrm{V}^{1}$., Ogbu Kenneth $\mathrm{I}^{2}$., \\ Olaosebikan O.O ${ }^{3}$. and Onu Euslar N. ${ }^{4}$ \\ ${ }^{I}$ Department of Applied Microbiology, Ebonyi State University, Abakaliki, Nigeria. \\ ${ }^{2}$ Department of Biological Sciences, Ebonyi State University, Abakaliki, Nigeria. \\ ${ }^{3}$ Department of Biology, Microbiology and Biotechnology Faculty of Science, Federal University Ndufu-Alike \\ Ikwo, Nigeria. \\ ${ }^{4}$ Ebonyi State School of Health Mgbo, Ohaukwu Local Government Area, Ebonyi State, Nigeria.
}

\begin{abstract}
The Fungal quality of fresh shrimp collected from Ndibe-beach in Afikpo North Local Government Area of Ebonyi State, Nigeria was investigated using standard microbiological procedures. A total of $60 \mathrm{~g}$ samples sourced from three vendors $(A, B$, and $C)$ within the beach was used for the study. The shrimp samples were categorized according to size into big, medium and small. These sizes were divided into head, body and tail. The result of this study revealed that the average fungal loads are: $2.07 \times 10^{6,} 0.39 \times 10^{6}$ and $0.79 \times 10^{6}$ for head, body and tail respectively. Also five fungal isolates were identified which include: Aspergillus spp, Fusarium spp, Penicillium spp, Rhizopus spp and Mucor spp. The result on percentage frequency of occurrence of the fungi revealed that Aspergillus and Fusarium species have the highest frequency of occurrence of $8(25 \%)$ for vendor A, Aspergillus at 7(28\%) for vendor B and also Aspergillus at 7(27\%) for vendor C while Rhizopus species have the lowest frequency of occurrence at 4(12.5\%), 4(16\%) and 3(11.5\%) for vendors $A, B$ and $C$ respectively. These results showed that the fresh shrimp may have been contaminated either by the handlers (mongers) or the environment the shrimp is gotten from and these can lead to food poisoning if not adequately cooked before consumption.
\end{abstract}

Keywords: Fresh shrimp, Ndibe beach, Food poisoning and Fungi.

\section{Introduction}

Shrimps are decapods swimming crustaceans classified in the infia order caridea. They are found near the sea floor of most coasts including estuaries and in well, rivers and lakes. Marine species are found at depths of up to $5,000 \mathrm{~m}(16,000 \mathrm{ft})$, [1]. Shrimps have high levels of omega 3 fatty acids and low levels of mecury [2]. High in calcium, iodine and protein, essential mineral and vitamins but low in food energy [3]. Shrimps based meal is also a significant source of cholesterol from $122 \mathrm{mg}$ to $251 \mathrm{mg}$ per $100 \mathrm{~g}$ of shrimps. Shrimps consumption is considered healthy for the circulatory system because of the lack of significant saturated fat in shrimps meaning that the high cholesterol content in shrimps actually improves the ratio low density lipid to high density lipid, cholesterol and lowers triglyceraldehydes [4].

Shrimps are a small free swimming edible crustaceans with two legs. It is basically marine and commonly found in estuaries and along coastal waters. However, its primary habitata is muddy bottom area from inter tidal zone to approximately $110 \mathrm{~m}$ with greatest density occuring at depths between 27 to $55 \mathrm{~m}$ [5].

Brown shrimps are scavengers generally termed bottom feeding opportunistic omnivores which means that they feed on most organic materials, dead plants and animal matter that they encounter at the bottom. They consume some algae species. Invertebrates such as copepods, annelids, and mollusks [6 and 7].

Shrimps between the size of 65 to $100 \mathrm{~m}$ in lenght become predatory, feeding on annelids, worms, nematodes, and zooplankton larva [8]. Shrimps apart from being of great nutritional value to the customers also serve as an ideal culture media for microorganisms which connotes spoilage. Despite all the benefits associated with shrimps, one thing still remain clear and yet unsolved; shrimps are highly prone or susceptible to rapid deterioration immediately after harvest, microorganisms are undoubtebly responsible for the spiolage of shrimps and these microorganisms include bacteria and fungi. One important characteristics of microorganisms is that they grow rapidly and increase in number [9].

Mold which belong to fungi grow well in moist condition. They take advantage of the moist condition available and through the aid of enzymes which they posess, they weaken and penetrate the protective outer layer of the shrimp and cause spoilage. It is almost always possible to detect a range of human pathogen on any shrimp that has not received any microbial treatment [10].

Some of the pathogens may constitute part of the normal flora on the shrimp or be present as a result of unavoidable contamination [11]. Also a normal micro flora of human can cause spoilage of shrimps by ways of 
contamination through handlers as they touch the shrimps with bare hands in the bid of harvesting and selling the shrimps. Also shrimps spoilage based on microbial origin are mainly from the shrimp environment and in this environment, contamination may occur as a result of the presence of microorganisms through faecal means into water bodies. Fresh brown shrimps sold in the market do not undergo any form of microcidal treatment and are not iced before sale. The shrimp mongers also handle them with bare hands durring transportation. Some shrimp customers cook the shrimp whole while others remove the head and tail of the shrimp before consumption. There is therefore need to acertain the microorganisms associated with this various parts of shrimps and the health hazard associated with the type of microorganism. The knowledge of the type of microorganisms help to control shrimp spoilage.

\section{Aim of the study}

To identify and isolate fungi associated with fresh shrimps sold at Afikpo Beach.

Objectives

1. To deterimine the frequency of occurrence of fungi in the Head, Body and Tail of the shrimp

2. To determine the safety of consumption of the shrimp

\section{Study Area}

\section{Materials and Methods}

The study was carried out in Ndibe beach, Afikpo North L.G.A in Ebonyi State South East Nigeria, geographically it is located on latitude $6^{\circ} \mathrm{N}$ and longitude $8^{0} \mathrm{E}$ of the Greenwich meridian with the estimated population of 156,611 according to the Nigeria 2006 census.

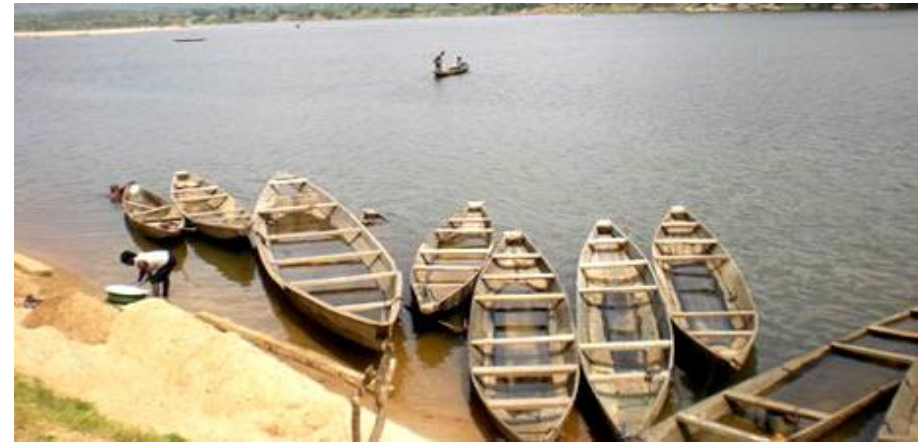

Fig: 1: Ndibe beach (River)in Afikpo North Local Government Area of Ebonyi State.

\section{Materials}

Materials used for this study are in a detailed list shown on appendix I.

Media Preparation

All the media used were prepared according to the manufacturer's specification as shown in the appendix II

\section{Collection of Samples}

60 grams of fresh shrimp each were purchased from four different vendors within Ndibe beach market the Shrimps were immediately transported in a sterile plasticbags with ice block to the Microbiology laboratory unit of Ebonyi State University for identification and analysis.

\section{Sample Identification}

The fresh shrimp sample was identified as Macrobranchium vollenhouenii by Mr. Uho Cosmos, a taxonomist in Applied Biology Department of Ebonyi State University.

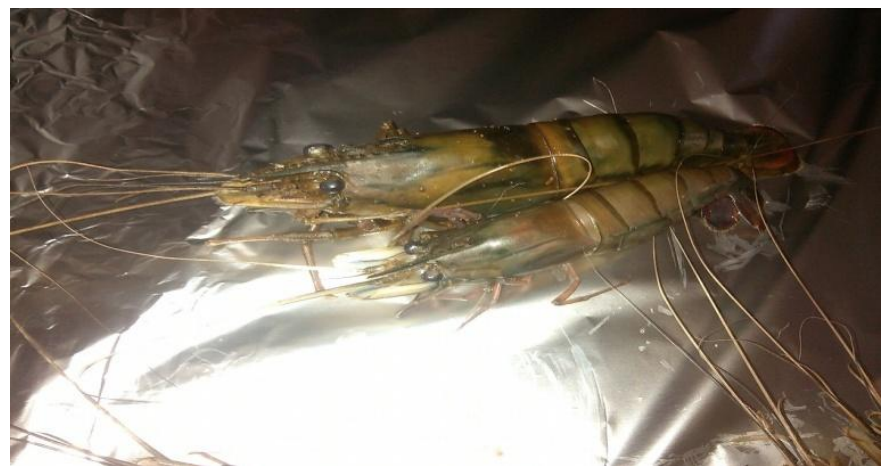

Fig 2: Pictures of fresh harvested shrimps from Ndibe beach 
Fungal Quality of Fresh Shrimp Sold at Ndibe-Beach in Afikpo, Ebonyi State.

\section{Analysis procedure}

The shrimp from each of the three vendors were aseptically divided into head, body and tail with a surgical blade. Each part was pounded using a sterile porcelain mortar and pistle and kept differently. A $10 \mathrm{~g}$ portion of each (head, body and tail) from the different vendors was weighed out and homogenized with 90ml of peptone water for $10 \mathrm{mins}$. $1 \mathrm{ml}$ each of dilution five (5) of the homogenate was pour plated on Sabouraud Dextrose Agar (SDA) and incubated for $72 \mathrm{hrs}$ at $37^{\circ} \mathrm{C}$. Discrete colonies were counted and subcultured onto a fresh SDA plates inhibited with chloramphenicol and incubated for 3-4 days after which the plates were examined.

\section{Characterization and identification of fungi isolate}

The fungi isolate were identifed on the bases of colonial morphology followed by microscopic examination after lactophenol staining.

\section{Lactophenol staining}

Little portion of the fungal isolate was mixed in a drop of lactophenol cotton blue stain made on a clean grease free microscopic slide using sterile wireloop, a smear was made and covered with a sterile cover slip. It was observed under the microscope using x10 and x40 objective lenses for detection of features as hyphae, mycelium and spore [12].

\section{Results}

The result of total plate count of fungi from fresh shrimp collected from Ndible beach in Afikpo North Local Government Area of Ebonyi State Nigeria is shown in table 1. It revealed that the average fungal colonies from different sample parts are $2.07 \times 10^{6}, 0.39 \times 10^{6}$ and $0.79 \times 10^{6}$ for head, body and tail respectively.

The result on the descriptional features of the fungal isolates from the shrimp is shown in table 2 . It shows that five (5) fungal isolates were identified which include Aspergillus species, Fusarium species, Mucor species, Penicillum species and Rhizopus species. All the fungal isolates are Lactophenol positive.

The result on the percentage frequency of occurrence of the fungal isolates from the shrimp collected from three vendors is shown on table 3. It revealed that for vendor A, Aspergillus species and Fusarium species have the highest percentage frequency of $8(25 \%)$ respectively while Rhizopus species has the lowest percentage frequency of $4(12.5 \%)$.

For vendor B, Aspergillus species have the highest frequency of 7(28\%) while Fusarium species and Rhizopus species have the lowest percentage frequency of 4(16\%) respectively.

For vendor C Aspergillus species have highest percentage frequency of 7(27\%) while Rhizopus species have the lowest percentage frequency of 3(11.5\%). In summary, Aspergillus species has the highest frequency and Rhizopus species have the lowest frequency in all the samples surveyed.

Table 1: Total plate count of fungi from fresh shrimp

\begin{tabular}{|l|l|l|}
\hline Source & No of colonies counted & Fungi count $\left.\mathbf{x} \mathbf{1 0}^{\mathbf{6}} \mathbf{( c f u} / \mathbf{m l}\right)$ \\
\hline HA & 250 & 2.50 \\
\cline { 2 - 3 } HB & 186 & 1.86 \\
\cline { 2 - 3 } HC & 186 & 1.86 \\
\cline { 2 - 3 } BA & 36 & 0.36 \\
\cline { 2 - 3 } BB & 32 & 0.32 \\
\cline { 2 - 3 } BC & 50 & 0.50 \\
\cline { 2 - 3 } TA & 120 & 1.20 \\
\hline TB & 80 & 0.80 \\
\hline TC & 36 & 0.36 \\
\hline
\end{tabular}

Average fungi count for head, body and tail are $2.07 \times 10^{6}, 0.39 \times 10^{6}$ and $0.79 \times 10^{6}$ respectively.

Key: $\begin{array}{lll}\text { HA } & - & \text { Head from vendor A } \\ \text { HB } & - & \text { Head from vendor B } \\ \text { HC } & - & \text { Head from vendor C } \\ \text { BA } & - & \text { Body from vendor A } \\ \text { BB } & - & \text { Body from vendor B } \\ \text { BC } & - & \text { Body from vendor C } \\ \text { TA } & - & \text { Tail from vendor A } \\ \text { TB } & - & \text { Tail from vendor B } \\ \text { TC } & - & \text { Tail from vendor C }\end{array}$


Fungal Quality of Fresh Shrimp Sold at Ndibe-Beach in Afikpo, Ebonyi State.

Table 2: Descriptional features of fungi isolates

\begin{tabular}{|l|l|l|l|c|c|}
\hline $\mathbf{S} / \mathbf{N}$ & Colour & Consistency & Microscopy features & $\begin{array}{l}\text { Lactophenol } \\
\text { cotton blue }\end{array}$ & $\begin{array}{l}\text { Suspected } \\
\text { fungal isolate }\end{array}$ \\
\hline $\mathbf{1}$ & Nearly green & Grey fluffy mycelium & $\begin{array}{l}\text { chains of single cell } \\
\text { Conidia spherical, rod and } \\
\text { regular in size }\end{array}$ & $\begin{array}{l}\text { Penicillium } \\
\text { species }\end{array}$ \\
\hline $\mathbf{2}$ & $\begin{array}{l}\text { Greenish } \\
\text { brown, white to } \\
\text { black }\end{array}$ & $\begin{array}{l}\text { Rough walled } \\
\text { forming long dry chain } \\
\text { grayish }\end{array}$ & $\begin{array}{l}\text { Flask Shaped Phialides, } \\
\text { branching at 45 chain and }\end{array}$ & + & $\begin{array}{l}\text { Aspergillus } \\
\text { species }\end{array}$ \\
\hline $\mathbf{3}$ & $\begin{array}{l}\text { Phitish to } \\
\text { dark brown }\end{array}$ & $\begin{array}{l}\text { Fluty, rose or } \\
\text { purple pigment } \\
\text { surface }\end{array}$ & $\begin{array}{l}\text { Irregular Conidiosphore and } \\
\text { in Clusters }\end{array}$ & + & Mucor species \\
\hline $\mathbf{5}$ & Black & Cotton like & $\begin{array}{l}\text { Irregular } \\
\text { sporangiosphore, } \\
\text { contains root like Rhizoids }\end{array}$ & + & $\begin{array}{l}\text { Fusarium } \\
\text { species }\end{array}$ \\
\hline
\end{tabular}

Key: $+=$ positive

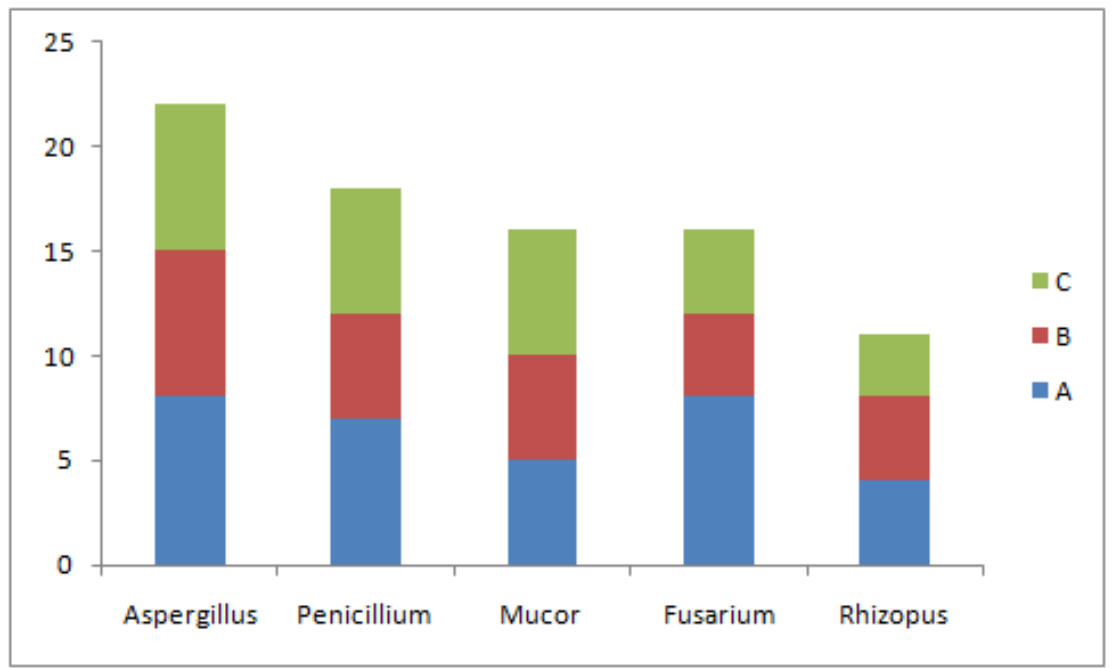

Figure 3: Percentage frequency of occurrence of fungal isolated from fresh shrimp from vendor A, B and C.

\section{KEY}

\section{Vendor A}

\section{Vendor B}

Vendor C

\section{Discussions}

High fungi isolates was observed in the fresh shrimp sample this is attributed to improper handling and contamination from the shrimp environment. The result shows that Aspergillus, Penicillum and Fusarium species are higher in number on the shrimp; this is in line with the study carried out by Lidiane et al., (2011), [13], who reported that the highest genera of fungi that attack Litopenaeus vannamei shrimps are Aspergillus, Fusarium and Penicillin species. This is also in line with Obire et al., (2011), [14], that reported to isolate Penillium, Fusarium, Aspergillus, Rhizopus, and Mucor from shrimp before and after detoriation. Most of the fungi species isolated have been separated as mycoses agent in human causing skin infections, Aspergillosis, liver furor, fungal balls in the lungs ,chronic productive cough and haemoptyes bronchial asthma, infection of the ear or paranasal sinuses, necrosis and eventual abscesses and varicose dermatitis, a chronic human mycosis [15].

Aspergillus species was the most prevalent species in all part of the shrimp and the most powerful fungal species to produce aflatoxins which are mycotoxins with carcinogenic potentials. The findings of this 
study showed the poor fungal quanlity of shrimp. These fungi have been associated with the spoilage of fresh shrimp.

\section{Conclusion}

This study present a significant diversity of culturable fungi in fresh shrimp sold in Ndibe beach in Afikpo North Local Government Area Ebonyi State as at that time of this study. The presence of these fungi in the shrimps is attributed to contamination from the environment and from shrimp handlers (mongers). Also some of these fungi are normal flora of the shrimp which unfortunately happens to be opportunistic pathogen or pathogens of humans. The maintenances of high personal and environmental hygiene as well as proper heating and cooking will improve fresh shrimp quality and reduce food borne diseases it is important that brown shrimp and other sea food product be properly and adequately cooked, Also unfavorable conditions should be created to prevent fungal growth, such condition are regulation of water holding capacity of the food, temperature and $\mathrm{pH}$.

\section{References}

[1] Fenner A. Chace, Jr. and Donald P. Abbott (1980). "Caridea: The Shrimps". In Robert Hugh Morris, Donald Putnam Abbott \& Eugene Clinton Haderlie. Intertidal Invertebrates of California. Stanford University Press. 567-576.

[2] Smith, K.L and Guentzel J.I (2010). Mercury Concentration and Omega3 Fatty Acid in Fish and Shrimps, Preferential Consumption for Maximum Health Benefit. Marine Pollution Bulletin, 6(9); 1615-1618.

[3] Jay J. M (1986a). Intrinsic and Extrinsic Parameters of Foods that Affect Microbial Growth. Modern food microbiology Van Nostrand Reinhold Co, NewYork.

[4] Elizabeth. R. De Oliveirae Silva, Cynthia E. Seidman, Jason J. Tian, Lisa C. Hudgins, Frank M. Sacks and Jan L. Breslow (1996). "Effects of Shrimp Consumption on Plasma Lipoproteins". American Journal of Clinical Nutrition, 64 (5): $712-717$

[5] Williams, A. B (1984). Shrimps, lobsters and crabs of the Atlantic coast of the Eastern United States, Marine to Florida. Smithsonian Institution Press. Washington, D C. 550.

[6] Dall W (1968). Food and Feeding of some Australian Penaeid Shrimp. World Science Conference on Biology and Cultivation Of shrimps and prawns. FAO Fisheries Reports, 57(2): 251-258.

[7] Odum WE, Herald E (1972). Trophic Analysis of an Estuarine Mangrove Community. Bulletin of Marine Science, 22(3): 671-738.

[8] Jones R. R. (1973). Utilization of Louisiana Estuarine Seiments as a Source of Nutrition for the Brown Shrimps, Penaeus Aztecus. Ph.D. Dissertation, Louisiana State University, Baton Rouge.

[9] Harrigan W.F and McCance M.E (1990). Charateristics of shrimp. Laboratory Methods in Food and Dairy Microbiology. 8th Edition. Academic Press, London 305-316.

[10] Okigbo RN and Ajalie AN (2005). Inhibition of Some Human Pathogens with Tropical Plants Extracts Chromolinaena odorata and Citrus aurantifolia and Some Antibiotics. International Journal of Molecular Medicine of Advanced Science (Pakistan) 1 (1): 34 40 .

[11] ICMSF (International Commission on Microbiology Specifications for foods) (1996). Microorganisms in Food. Characteristics of Microbial pathogens. Blackie Academy and Professionals. Cambridge University Press, U.S.A. 38-174.

[12] Cheesbrough M. (2004). District laboratory practice in tropical countries part 2. Cambridge University Press, U.S.A. 38-174.

[13] Lindiane Roberta, Cruz da Silva, Debora Maria Massa Lima, Odacy Camilo de Souza, Maria Jose dos Santos Fernandez, Rosalie Reed Rodrigues Coelho and Cristina Maria Souza-Motta (2011). Culturable fungal diversity of shrimp Litopanaeus vannamei boone from breeding farms in Brazil. Brazil journal of microbiology. 42(1):49-56.

[14] Obire O., Okigbo, R. N and Minimah T. R. (2003) Mycoflora of fresh shrimp penaeus azteus from different markets in part Harcourt Nigeria. Africa Journal of food science (8) 204-209.

[15] Anker S. T. Ahyong, P. Y. Noel, and A. R. Palmer (2006). "Morphological Phylogeny of Alpheid Shrimps: Parallel Preadaptation and The Origin of a Key Morphological Innovation, The Snapping Claw". Evolution, 60 (12): 2507-2528. 